\title{
Phytochemical and Anti-microbial Screening of Phyllantus fratenus and Taraxacuim officinale Leaves
}

\author{
Edori OS*, Marcus AC, Maduagu MC \\ Department of Chemistry, Ignatius Ajuru University of Education, P.M.B. 5047, Rumuolumeni, Port Harcourt, Nigeria
}

\begin{abstract}
Dry and powdered leaves of Phyllantus fratenus and, Taraxacum officinale were subjected to different solvent extraction using chloroform, methanol and hexane. The extracts were examined for the phytochemical components present in them. It was observed that in Phyllantus fratenus; fats and oil, tannins, saponins, coumarins were present the chloroform extract, alkaloids, glycosides, tannins and coumarins were present in the methanol extracts and in the hexane extract, alkaloids, glycosides, flavonoids and coumarins were present. In Taraxacum officinale; alkaloids, fats and oil, tannins, saponins, flavonoids, terpenoids and steroids were present in chloroform extracts, alkaloids, flavonoids, terpenoids and steroids were present in the methanol extract and in hexane extract, it was only alkaloids and terpenoids that were present. The microbial activity of the various solvent extracts of the different plants showed that the chloroform extracts of both plants were active against S. auereus, and V. cholera, but it was only T. officinale extract that was active against E. coli. In the hexane extracts of both plants, the growth of S. aureues was inhibited in both plants extract, $V$. cholera growth was only inhibited in P. fratenus extract and E. coli was only inhibited in T. officinale extract. In the methanol extracts of both plants, s. aureus was inhibited in T. officinale extract, V. cholerae was inhibited in both plant extracts and E. coli was only inhibited in T. officinale extract. The observations on the antimicrobial activities of the various plant extracts indicated the reasons of their applications in herbal drug dispensation.
\end{abstract}

Keywords: Phytochemicals; Antimicrobial activity; Plant extracts; Phyllantus fratenus; Taraxacuim officinale

\section{INTRODUCTION}

Man, from origin has been in search for new drugs. Different medicinal plants which possess healing uses have been identified and new ones being discovered [1]. Plants have the capacity to translate the energy from the sun to chemical products or metabolites, which are consequently converted to food and medicine for use by man and animals [2]. According to estimate from the World Health Organization (WHO), $80 \%$ of the total world population particularly those in developing countries utilize mostly plant parts as traditional medicine for their main health care, through the use of plant extracts [3].

Although the medicinal characteristics of plants is a common knowledge, yet their importance has not been satisfactorily coupled for man's use. This is due to improper documentation or records of known herbal plants and variation in application which differs from one tribe to the other and one herbalist to the other [4].

The importance or herbal medicines lies in their environmental friendliness and low cost when compared with laboratory processed or synthetic drugs in medicinal stores [5]. Due to the fact that herbal drug possess multi-targeting effect, inexpensive and safety of plant based products when compared to synthetic drugs, there is a continuous rise in the search and discovering of new drugs of plants origin [6].

Notwithstanding the circumstance, indigenous medical practices have attracted much attention in different fora and disciplines, even though the mode of action and clinical efficiency of most indigenous medicinal plants have not been well-known to agreeing to modern requirements of pharmacognosy and pharmacology [7].

Nevertheless, this is not sufficient to question the alternative use of herbal medicine, since the use of synthetic products stems from the modification of the structure and functions of some natural products.

Both primary and secondary metabolites are produced from plants. The primary metabolites refers to the proximate components which are elementary cell metabolites such as sugars, protein, lipids etc, and the secondary metabolites (phytochemical components),

${ }^{*}$ Correspondence to: Edori OS, Department of Chemistry, Ignatius Ajuru University of Education, P.M.B. 5047, Rumuolumeni, Port Harcourt, Nigeria, Tel: 08038984391; E-mail: onisogen.edori@yahoo.com

Received: December 17, 2019; Accepted: January 15, 2019; Published: January 22, 2019

Citation: Edori OS, Marcus AC, Maduagu MC (2019) Phytochemical and Anti-microbial Screening of Phyllantus fratenus and Taraxacuim officinale Leaves. Biochem Anal Biochem 8:376. doi: 10.35248/2161-1009.19.8.376.

Copyright: (C) 2019 Edori OS, et al. This is an open-access article distributed under the terms of the Creative Commons Attribution License, which permits unrestricted use, distribution, and reproduction in any medium, provided the original author and source are credited. 
the end products of the primary metabolites which have a variety of structural arrangements and properties and not certainly be involved in the essential breakdown or build-up of the cell [8].

Most plants used in traditional medication have bioactive constituents which are not fully known. In most studies on herbal plants, consideration is mostly on their effects on biological systems based on their applicability or use, without giving adequate attention to the different components or combinations which the plant contains. Based on this fact, the investigation or exploration of these plants should be carried out with respect to their use [9] and this should include both chemical and biological assessment [10].

Microorganisms are the predominant disease-causing agents. Also, they are responsible for most ill health and death recorded worldwide. In the world presently, there is a growing spate of drug resistant microorganisms which has resulted in non-effectiveness of some drugs presently in use. This state has provided the motivation for the quest for new and effective antimicrobial constituents from numerous sources like curative plants. The plants by tradition have given a source of anticipation for innovative drug combinations, thereby providing huge influences or contributions to the wellness and health of humans. Therefore, the use of plant extracts which possess antimicrobial characteristics can be very useful and significant for therapeutic uses [11].

This study therefore was carried out to examine the phytochemical composition and anti-microbial potentials of the different solvent extracts of Phyllantus fratenus and Taraxacuim officinale Leaves.

\section{MATERIALS AND METHODS}

\section{Source and preparation of plants}

Fresh leaves of Phyllantus fratenus and, Taraxacum officinale were obtained from Obite and Port Harcourt in Rivers State, Nigeria. The fresh leaves were washed and air dried to constant weight. The plants were blended to powder using an electric blender and stored in air-tight bottles.

\section{Solvent extraction of the plants}

The extraction of the different plant extracts and preservation of the extracts was done according to the method of Obomanu et al. Precisely, $50 \mathrm{~g}$ of each powdered dried leave were extracted for 72 hours using different solvents (chloroform, methanol and hexane) in a $200 \mathrm{ml}$ beaker and later transferred to an air tight bottle to avoid escape of the solvent. The sample was filtered using muslin cloth and later, filter paper. Extract obtained was kept in an air tight bottle until it was used for phytochemical screening and biological test.

\section{Phytochemical examination of the plants}

The Wagner's test was used for identification of alkaloids in the plant extracts. A few drops of $1 \% \mathrm{HCl}$ was added to $3 \mathrm{ml}$ of the extracts in a test tube and the extract: $\mathrm{HCl}$ mixture heated for 15 mins, allowed to cool and 2 drops of Wagner reagent was dropped to the mixture and observed for a reddish-brown precipitate which indicated the presence of Alkaloid [12].

Alkaline reagent test was used to determine the presence of flavonoids. Sodium hydroxide solution was added to $3 \mathrm{ml}$ of the extract and observed for the formation of an intense yellow colour.
On addition of few drops of dilute acid $\left(\mathrm{H}_{2} \mathrm{SO}_{4}\right.$ or $\left.\mathrm{HCl}\right)$ it turns colourless thereby showing the presence of flavonoids [13].

To examine for the presence of saponins, the frothing Test was performed. $3 \mathrm{ml}$ of the extract in a test tube was mixed with $5 \mathrm{ml}$ of distilled water and shaken vigorously for 2 minutes. The formation of stable form or froths established the presence of saponins [14].

When 3 drops of concentrated $\mathrm{H}_{2} \mathrm{SO}_{4}$ is added to $3 \mathrm{ml}$ of the extract and a red colouration is observed, indicated the presence of steroids.

The test for tannins was done by adding $10 \%$ of freshly prepared $\mathrm{KOH}$ to $3 \mathrm{ml}$ of the extract in $\mathrm{Mn}(\mathrm{OH})_{2}$ and observed for dirty white precipitate, which authenticates the presence of tannins.

Test for terpenoids was conducted by mixing $3 \mathrm{ml}$ of the extract with $2 \mathrm{ml}$ of $\mathrm{CHCl}_{3}$ in a test tube. Thereafter, $2 \mathrm{ml}$ of concentrated $\mathrm{H}_{2} \mathrm{SO}_{4}$ was added gently to form a ring layer which interfaced with a reddish-brown colour, thus indicating the presence of terpenoids [15].

A mixture of $3 \mathrm{ml}$ of the extract, $2 \mathrm{ml}$ of $40 \% \mathrm{NaOH}$ and few drops of $5 \% \mathrm{CuSO}_{4}$ were added together and observed for a violet or pink colour, which showed the presence of protein in the sample [16].

To $10 \mathrm{~cm}^{3}$ of concentrated $\mathrm{H}_{2} \mathrm{SO}_{4}$ was added to $3 \mathrm{ml}$ of the extract and the mixture heated for 15 minutes in a boiling water bath. Thereafter, $10 \mathrm{~cm}^{3}$ of Fehling solution was added to it while still boiling and observed for a brick red colour, which is an indication of the presence of glycosides [17].

The test for fats and oil was done by the stain or spot test method, where a little amount of the extract was dropped in between two filter papers and observed for oil stain [18].

Coumarin test was conducted the addition of $10 \% \mathrm{NaOH}$ to $3 \mathrm{ml}$ of the extract. The presence of coumarin was detected by the appearance of fluorescence blue-green colour [19].

\section{Collection of bacteria species and preparation}

Bacterial isolates (E. coli, S. auereus, and V. cholerae) were obtained from the Microbiological Unit, University of Port Harcourt Teaching Hospital (UPTH), Choba, Port Harcourt, Rivers State. They were incubated at $37^{\circ} \mathrm{C}$ for 24 hours and stock cultures prepared. A loop-full of the cultured bacterial was collected from its stock with a sterile wire-loop and injected into a test-tube of $5 \mathrm{ml}$ Mueller-Hinton broth. The broth was then incubated at $37^{\circ} \mathrm{C}$ for 6-hours [20]. Thereafter, the turbidity of the broth culture for the different pathogens were adjusted with sterile saline water to cell concentration of $3.0 \times 10^{8}$ cells $/ \mathrm{ml}$.

\section{Anti-bacterial screening of the plant extracts}

The antibacterial effect of the different plant extracts on the pathogenic bacteria species was done via the disc diffusion assay method. In this method, sterile test discs $(6 \mathrm{~mm}$ diameter $)$ were impregnated with the $10 \mathrm{mg} / \mathrm{ml}$ concentration of the different extracts and dried at $45^{\circ} \mathrm{C}$ in a hot air oven until the discs are completely dried [21]. One millilitre $(1 \mathrm{ml})$ of each pathogenic bacteria species, with the cell concentration of $3.0 \times 10^{8}$ cells $/ \mathrm{ml}$, was then seeded into recently prepared Mueller-Hinton agar plates using the pour-plating method and allowed to solidify [22]. The different test discs of the different extracts of different plant species were placed on the surface of the disc accordingly and labeled 
appropriately. The plates were then incubated at $37^{\circ} \mathrm{C}$ for 24 hours. After incubation, the zones of inhibition for the different extracts of the different plant species were measured in millimetres $(\mathrm{mm})$ and recorded [23].

\section{RESULTS}

The phytochemical screening of Phyllantus fratenus in chloroform extract showed the presence of fats and oil, tannins, saponins and coumarin. While the methanol extracts showed the presence of alkaloids, glycosides, tannins, and coumarin. The hexane extracts showed the presence of alkaloid, glycosides, flavonoids and coumarin. Terpenoids, steroids and proteins were not present in any of the solvent extracts from the plant. The phyllantus extracts however, showed more positive results in the methanol extract than the chloroform and hexane extracts (Table 1).

The phytochemical screening of Taraxacum officinale extracts indicated the presence of alkaloids and terpenoids in all the three solvent (chloroform, methanol and hexane) extracts. Flavonoids and Steroids were only present in chloroform and methanol extracts. While fats and oil, tannins and saponins were present in

Table 1: Phytochemical composition of Phytallus fratenus from different solvent extracts.

\begin{tabular}{lccc}
\hline \multirow{2}{*}{ Phytochemicals } & \multicolumn{3}{c}{ Solvents } \\
\cline { 2 - 4 } & Chloroform & Methanol & Hexane \\
\hline Alkaloids & - & + & + \\
\hline Fats and oil & + & - & - \\
\hline Glycosides & - & + & + \\
\hline Tannins & + & + & - \\
\hline Saponins & + & - & - \\
\hline Flavonoids & - & - & + \\
\hline Terpenoids & - & - & - \\
\hline Steroids & - & - & - \\
\hline Proteins & - & - & - \\
\hline Coumarins & + & + & + \\
\hline
\end{tabular}

Table 2: Phytochemical composition of Taraxacuim officinale from different solvent extracts.

\begin{tabular}{lccc}
\hline Phytochemicals & \multicolumn{3}{c}{ Solvents } \\
\cline { 2 - 4 } & Chloroform & Methanol & Hexane \\
\hline Alkaloids & + & + & + \\
\hline Fats and oil & + & - & - \\
\hline Glycosides & - & - & - \\
\hline Tannins & + & - & - \\
\hline Saponins & + & - & - \\
\hline Flavonoids & + & + & - \\
\hline Terpenoids & + & + & + \\
\hline Steroids & + & + & - \\
\hline Proteins & - & - & - \\
\hline Coumarins & - & - & -
\end{tabular}

Table 3: Biological activity of the plant extracts from different solvents against different pathogens.

\begin{tabular}{lcccccc}
\hline Pathogen & \multicolumn{2}{c}{ Chloroform extract } & \multicolumn{2}{c}{ Hexane extract } & \multicolumn{2}{c}{ Methanol extract } \\
\cline { 2 - 7 } & P. fratenus & T. Officinale & P. fratenus & T. Officinale & P. fratenus & T. Officinale \\
\hline S. aureus & 7.7 & 7.7 & 7.8 & 7.8 & $\mathrm{R}$ & 9.2 \\
\hline V. cholerae & 8.9 & 7.9 & 9.1 & 8.1 & 8.8 & $\mathrm{R}$ \\
\hline E. coli & $\mathrm{R}$ & 8.1 & $\mathrm{R}$ & 8.9 & 8.7 \\
\hline
\end{tabular}

only chloroform extract. Glycosides, proteins and coumarin not detected in any of the extracts (Table 2).

The antimicrobial activity of the various solvent extracts of both plants showed that all the different solvent extracts inhibited the activity of $S$. aureus, except the methanol extract of $P$. fratenus. However, the methanolic extract of T. officinale offered the greatest inhibition to $S$. aureus. Growth of $V$. cholera bacteria was inhibited in chloroform and methanol extract both plants and hexane extract of P.fratenus, but was resistant to hexane extract of $T$. officinale. The E. coli bacterial strain was resistant to the effect of all the solvent (chloroform, hexane and methanol) extracts of $P$. fratenus, but were inhibited in all the solvent extracts of T. officinale (Table 3).

\section{DISCUSSION}

The presence of these chemical substituent referred to secondary metabolites is known to be responsible for the health applications of plant for curative purposes. The application of Alkaloids for therapeutic applications have been known for many centuries ago. They possess cytotoxic properties [24] and analgesic characteristics. When they are present in plants, the possibility of the plant poison is increased. The bitter taste of alkaloids prevents plants from attack by many insect pest and predators. Cardiac glycosides inhibit the pumping of sodium/potassium ion and therefore increases the concentration of $\mathrm{Na}^{+}$in the myocyte, which helps in the total increase of calcium ions available to the heart muscles. This helps to positively facilitate heart functions by reducing congestion in the heart, and therefore act as a good agent for the control and failure of hearth. Controlled intake of cardiac glycosides, helps in arresting cardiac arrhythmia and give strength to a weak heart, thus helping the herat perform more efficiently [25].

Tannins have been documented to retain functional and severe haemostatic characteristics that facilitates the healing of wound and enhance irritated mucus membrane and also impede the development of bacteria [26]. This action is achieved through the precipitation of proteins in bacteria, thus hindering the utility of proteins by bacteria, with the resultant retardation of protein manufacture within the cells [27].

Saponins is very important in the treatment of cough and in the controlling of soreness of the upper respirational region. Furthermore, plant based saponins serve as heart tonic naturally and have been documented to prevent diabetics and hinder the growth of fungi [28].

The importance of Flavonoids lies in the fact that it controls and prevent tissue damage due to the presence of triggered, radical or singlet oxygen species [29]. Furthermore, flavonoids possess several biological characteristics. They act as vasodilators, prevents swelling of body tissues, acts as antioxidants, anti-microbial and increases the effectiveness of the immune systems. Steroids are known vital heart tonics. They have the capacity to prevent insects and bacterial attacks. They are introduced into cosmetics, food and work effectively in herbal medicine to increase strength. Their deep and effective inhibition of microbial growth makes 
them relevant in traditional health services or applications $[25,30]$. Terpenes or terpenoids are a group of organic compounds produced by plants. They possess strong odour which repels plant eating insects and animals. The smell also attracts predators and parasites of herbivorous animals. The functional group of some of the classes of terpenoids or terpenes contain oxygen while others are hydrocarbons [31]. They contain primarily essential oils found in therapeutic plants, which equally serves for fragrance and aromaticity in cosmetics production. A typical example of a terpene is vitamin A [32].

The coumarins are important because of their biotic characteristics. They possess physiologic functions, and inhibits bacterial and cancer growth. Coumarin together with some of its derivatives and are known probable inhibitors of cell propagation in several carcinoma cell shapes [33]. Coumarins display healing result through competitive inhibitors in the thickening flow pathway. They prevent the role of vitamin $\mathrm{K}$ that promotes the biological manufacture of prothrombin. In essence, coumarins show the expected healing consequence of anticoagulation through the control of plasma changeability and the elimination of poisonous effect of hemorrhage [34]. Due to the advantages of environmental safety, less toxicity, availability, cost effectiveness and their effect on enormous quantity of microorganisms, herbal drugs have been used to achieve the treatment of different bacterial attacks. The antibacterial potentials and mode of action of plant extract against microorganisms have been documented extensively [35]. The effects of the different extracts showed variation in the resistance offered by the tested microbes or bacteria. The active principles of resistance or inhibition of plant extracts on bacterial strains is dependent on the presence and nature of phytochemicals in the plant examined and also on the concentrations of the different phytochemicals extracted [36-38], the nature of the plant, the species and nature of the microorganism tested and the solvent type used for the extraction. The active principles or phytochemicals is the basis of medical potency or effectiveness of medicinal plants [35].

The bacterial pathogens examined has been known to disease causative organisms and are prevalent. The tested result indicated $S$. aureus and $V$. cholera responded more positively to the extract effects than E. coli. This may be due the fact that E. coli offer more resistance to the applied plant extracts or that it has the capacity to neutralize the effect posed by the plant extracts. However, According to Bereksi et al. [39], E. coli has been identified as a resistant bacterial strain to many drugs and plant extracts.

The bacterial strain, E. coli resisted the effect of the different solvent extracts from Phytallus fratenus, but were inhibited in the solvent extracts of Taraxacum officinale. This difference may be associated with the difference in the phytochemicals extracted from the different plants. The differences between the two plant extracts only occurred in coumarins and glycosides which were present in Phytallus fratenus, while terpenoids and steroids were only detected in Taraxacum officinale extracts. The lower or non-response of E. coli to extracts of Phytallus fratenus could be owing to their capacity to form external pores that enabled it to resist the new environmental situations than the other examined microorganisms [22].

\section{CONCLUSION}

This study has shown that the plant extracts possess possible antimicrobial components which can fight against microbes.
Therefore, they can serve as useful herbal remedy for the cure and prevention of some diseased conditions caused by microorganism. If these plants are properly harnessed through further studies and produced through normal scientific approach, they could serve for alternative source of drug production.

\section{REFERENCES}

1. Verpoorte R, Memelink J. Engineering secondary metabolite production in plants. Curr Opin Biotechnol. 2002;13:181-187.

2. Abdul G. The State of Medicinal Plant Research in Nigeria. Unife Press. 1988;56-77.

3. Ajay KM, Parveen B, Sanjiv K. Plants-herb wealth as a potential source of ayurvedic medicine. Asian J Traditional Medicines. 2009;4:152-170.

4. Oliver-Bever B. Medicinal Plants in Tropical West Africa. Cambridge University Press. 1986;940.

5. Mann A, Yahaya Y, Banso A, John F. Phytochemical and antimicrobial activity of Terminalia avicennioides extracts against some bacteria pathogens associated with patients suffering from complicated respiratory tract diseases. J Medicinal Plant Res. 2008;2:094-097.

6. Shagal $\mathrm{MH}$, Kubmarawa D. Antimicrobial and phytochemical screening of Icacina trichantha. American J Biomedical Life Sciences. 2013;1:37-40.

7. Swain T. Plants in the Development of Modern Medicine Harvard University Press, Cambridge. 1972;125-129.

8. Trease GE, Evans WC. Antioxidant Activity of the Natural Flavonoid 7-Hydroxy-5,6,4' trimethoxyflavone Isolated from the Leaves of Lippia rugosa A. Chev. Pharmacology (13thedn), ELBS Bailliere Tindall, London. 1989;268-296.

9. Otun KO, Onikosi DB, Ajiboye AA, Jimoh AA. Chemical Composition, Antioxidant and Antimicrobial Potentials of Icacina trichantha Olive Leaf Extracts. Natural Products Chemistry Res. 2015;3:188.

10. Taylor JLS, Rabe T, McGaw LJ, Jager AK, Staden VJ. Towards the scientific validation of traditional medicinal plants. Plant Growth Regulation. 2001;34:23-37.

11. IMW, Duncan AR, Okunji CO J. ASHS Press Alexandra V.A. 1999;457-462.

12. Jamuna S, Subramaniam P, Krishnamoorthy K. Phytochemical analysis and evaluation of leaf and root parts of the medicinal herb, Hypochaeris radicata L. for in vitro antioxidant activities. Asian Pacific J Tropical Biomedicine. 2014;4:359-367.

13. Jia Z, Tang M, Wu J. The determination of flavonoid contents in mulberry and their scavenging effects on superoxide radicals. Food Chemistry. 1999;64:555-559.

14. Makkar HP, Siddhuraju P, Becker K. Methods in molecular biology: plant secondary metabolites. Totowa: Human Press. 2007;93-100.

15. Yanishlieva MNV. Inhibiting oxidation. In: Pokorny J, Yanishlieva N, Gordon MH (eds). Antioxidants in food: Practical applications. Woodhead Publishing Limited, Cambridge. 2001;22-70.

16. Kumar RS, Moorthy K, Vinodhini R, Punitha T. Antimicrobial efficacy and phytochemical analysis of Indigofera trita linn. African J Tradit Complement Altern Med. 2013;10:518-525.

17. Akande IS, Samuel TA, Agbazue U, Olowolagba BL. Comparative proximate analysis of ethanolic and water extracts of Cymbopogen citrates (lemongrass) and four tea brands. J Pharmacy Biomedical Sciences. 2012;3:29-35.

18. Sandhya BS, Thomas S, Isabel W, Shenbagarathai R. Ethnomedicinal plants used by the Valaiyan community of Piranmalai hills (Reserved 
forest), Tamil Nadu, India-A pilot study. African J Traditional Complementary Alternative Med. 2006;3:101-114.

19. Sofowara A. Medicinal plants and traditional medicine in Africa. Spectrum Books Ltd., Ibadan, Nigeria. 1982;256.

20. Liliwirianis N, Wan Z, Jamaluddin K, Shaikh AK. Antimicrobial activity of plant extracts against Bacillus Subtilis, Staphylococcus Aureus and Escherichia Coli. E-Journal of Chemistry. 2011;8:282-284.

21. Gulluce M, Sahin F, Sokmen M, Ozer H, Daferera D, Sokmen A, et al. Antimicrobial and antioxidant properties of the essential oils and methanol extract from Mentha longifolia L. ssp. longifolia. Food Chemistry. 2007;103:1449-1456.

22. Nascimento GGF, Locatelli J, Freitas PC, Silva GL. Antibacterial activity of plant extracts and phytochemicals on antibiotic resistant bacteria. Brazilian J Microbiology. 2000;31:247-256.

23. Dieudonné LN, Jules CN, Assob SEM, Dinga JN, Claude KY, Sandjon B. Antimicrobial activities of a plethora of medicinal plant extracts and hydrolates against human pathogens and their potential to reverse antibiotic resistance. Int J Microbiology. 2015.

24. Muselík J, García-Alonso M, Martín-López MP, Želmièka M, RivasGonzalo JC. Measurement of Antioxidant Activity of Wine Catechins, Procyanidins, Antocyanins and Piranoantocyanins. Int J Mol Sci. 2007;8:797-809.

25. Denwick PM. Natural products: A biosynthetic approach. 2nd Edition, Willey and Sons, Ltd. 2002;241-243.

26. El-Kamali HH, Elshikh AA. Preliminary phytochemical screening of 27 plants species use in ethnoveterinary in Khartoum State, Sudan. Advances in Life Sciences. 2015;5:48-52.

27. Ogunleye DS, Ibitoye SF. Studies of antimicrobial activity and chemical constituents of Ximenia Americana. Tropical J Pharmaceutical Res. 2003;2:239-241.

28. Kamel JM. An extract of the mesocarps of fruits of Balanitea egyptiaca exhibited a prominent anti-diabetic properties in Mice. Chemistry Pharmacology Bulletin. 1991;39:1229-1233.
29. Rice ECA, Packer L. Flavonoids in health and disease, Marcel Dekkar, New York. 1998;25.

30. Aiyelaagbe OO, Osamudiamen PM. Phytochemical screening for active compounds in Mangifera indica leaves from Ibadan, Oyo State. Plant Sci Res. 2009;2:11-13.

31. Davis EM, Croteau R. Cyclization enzymes in the biosynthesis of monoterpenes, sesquiterpenes, and diterpenes. Topics in Current Chemistry. 2000;209:53-95.

32. Pichersky E. Biosynthesis of Plant Volatiles: Nature's Diversity and Ingenuity. Sci. 2006;311:808-811.

33. Jain PK, Himanshu JH. Coumarin: Chemical and Pharmacological Profile. J Applied Pharmaceutical Sci. 2012;2:236-240.

34. Gilman's G. The Pharmacological basis of therapeutics: Blood coagulation and Anti-coagulant, thrombolytic and Anti-platelet drugs. 2006;1325-1328.

35. Okoye EI. Qualitative and Quantitative Phytochemical Analysis and Antimicrobial Screening of Solvent Extracts of Amaranthus hybridus (Stem and Leaves). Chemistry Res J. 2018;3:9-13.

36. Edori OS, Ekpete OA. Phytochemical screening of aqueous extract of Icacina trichantha roots and its effect on mortality of wood termite. World J Pharmaceutical Res. 2015;4:213-224.

37. Edori OS, Dibofori-Orji AN. Phytochemical composition and termiticidal effects of aqueous extract of Raphia farinifera. Scientia Agriculturae. 2016;13:97-102.

38. Edori OS, Marcus AC. Phytochemical Screening and Physiologic Functions of Metals in Seed and Peel of Citrullus lanatus (Watermelon). Int J Green Herbal Chemistry B. 2017;6:35-46.

39. Bereksi MS, Hassaïne H, Bekhechi C, Abdelouahid DE. Evaluation of Antibacterial Activity of Some Medicinal Plants Extracts Commonly Used in Algerian Traditional Medicine against Some Pathogenic Bacteria. Pharmacognosy J. 2018;10:507-512. 